\title{
FUNCTIONAL RECOVERY AFTER WHARTON'S JELLY-DERIVED MESENCHYMAL STEM CELL ADMINISTRATION IN A PATIENT WITH TRAUMATIC SPINAL CORD INJURY:A PILOT STUDY
}

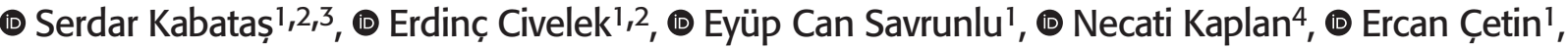 \\ (1) Furkan Diren ${ }^{1}$, (1) Osman Boyalı ${ }^{1}$, (1) Göksel Güven ${ }^{4}$ (1) Erdal Karaöz $z^{5,6,7}$
}

\author{
${ }^{1}$ University of Health Sciences Turkey, Gaziosmanpaşa Training and Research Hospital, Clinic of Neurosurgery, Istanbul, Turkey \\ ${ }^{2}$ Marmara University, Institute of Health Sciences, Department of Pediatric Allergy-Immunology, Istanbul, Turkey \\ 3 University of Health Sciences Turkey, Center for Stem Cell \& Gene Therapy Research and Practice, Istanbul, Turkey \\ ${ }^{4}$ Istanbul Rumeli University, Çorlu Reyap Hospital, Clinic of Neurosurgery, Tekirdağ, Turkey \\ 5 Istinye University Faculty of Medicine, Department of Histology and Embryology, Istanbul, Turkey \\ ${ }^{6}$ Liv Hospital, Center for Regenerative Medicine and Stem Cell Research \& Manufacturing (LivMedCell), Istanbul, Turkey \\ 7 İstinye University, Center for Stem Cell and Tissue Engineering Research and Practice, İstanbul, Turkey
}

The use of stem cells in the treatment of traumatic spinal cord injury (SCI) in recent years has provided promising results. Different sources of cells for transplantation have been used, including mesenchymal stem cells [MSCs; e.g., Wharton's jelly-derived (MSCs WJ-MSCs)]. Here, we reported on a 29-year-old man who was treated with WJ-MSCs in the course of therapy for blunt, traumatic SCI due to a work accident. He was operated on within 6 hours of the injury. Three and a half months later, he underwent intrathecal, intramuscular, and intravenous administrations of WJ-MSCs at a target dose of $1 \times 106 / \mathrm{kg}$ for each application route (twice a month for 2 months). All the procedures were tolerated well by the patient. In parallel to this, we have not seen any application-related complications so far. After stem cell infusions, progressive improvements were shown in the patient's neurological examination and neurophysiological and neuroradiological findings.

Keywords: Stem cell, transplantation, traumatic spinal cord injury, Wharton's jelly

\section{INTRODUCTION}

Spinal cord injury $(\mathrm{SCl})$ is a serious, debilitating condition affecting mostly young individuals. There have been many advances in the early surgical management and rehabilitation of these patients, resulting in improved survival but a lesser degree of functional improvement and independence ${ }^{(1)}$. The exact pathomechanism of $\mathrm{SCl}$ in humans remains blurry because most data about $\mathrm{SCl}$ have been acquired from animal models. An extensive interplay between various cells and molecules of the central nervous system (CNS), such as adhesion molecules, immune cells, and scar-forming cells, seems to be involved. It has been suggested that the extents of the astrocytic response and demyelination process are different between the pathomechanisms in humans and animal models; however, the fundamental events are similar ${ }^{(2)}$. $\mathrm{SCl}$ is a bi-phasic assault. In the first phase of $\mathrm{SCl}$, mechanical damage to the spinal cord results in the rupture of neuronal membranes and axonal damage ${ }^{(3)}$. Decreased blood flow causes hypoxia and diffuse swelling of the cord ${ }^{(4)}$. The secondary phase causes prolonged and widespread tissue damage resulting from interlinked events like excitotoxicity, ionic imbalance, oxidative stress, and immune and inflammatory responses ${ }^{(5,6)}$. But setting off of a multitude of vascular, biochemical, cellular, and molecular events exaggerates the inflammatory response and aggravates the lesion ${ }^{(7)}$. The current treatment for traumatic $\mathrm{SCl}$ is surgical decompression of the spinal cord and medical treatment, such as methylprednisolone steroid therapy ${ }^{(8)}$. Recent advances in neuroscience and regenerative

Address for Correspondence: Necati Kaplan, İstanbul Rumeli University, Çorlu Reyap Hospital, Clinic of Neurosurgery, Tekirdağ, Turkey Phone: +90 2826840200 E-mail: drnecatikaplan@hotmail.com Received: 03.11.2020 Accepted: 12.01.2021

ORCID ID: orcid.org/0000-0001-5672-0566 
treatments, along with an intense focus on cell-based therapy, have yielded promising results. Karaoz et al.(9) suggested that transplantation of rat pancreatic islet-derived stem cell ( $\mathrm{rPI}-$ MSCs) in the contused spinal cord improved locomotor recovery. Reduction of inflammation factors after rPI-SCs transplantation might be effective for functional outcomes following traumatic injuries to the spinal $\operatorname{cord}^{(9)}$.

\section{CASE PRESENTATION}

The presented pilot study was a prospective, longitudinal medical experiment. The study was performed at the University of Health Sciences Turkey, Gaziosmanpaşa Training and Research Hospital, İstanbul, Turkey. The MSC trial was approved by the Turkish Ministry of Health (protocol number: 56733164203-E.2569). The patient was informed of the procedure, and a written informed consent form was obtained per the Helsinki Declaration. The general data collected before the experimental therapy consisted of age, gender, cause of the $\mathrm{SCl}$, length of time since the $\mathrm{SCl}$, previous medical treatment for the $\mathrm{SCl}$, and past medical history.

\section{Medical History}

The patient was a 29-year-old male who had fallen from a power pole and was admitted to a private hospital's emergency room in a paraplegic condition. He had been diagnosed with a T5-6 fracture dislocation and blunt, traumatic $\mathrm{SCl}$, which can be stated as a mid-thoracic (T6) American Spinal Injury Association (ASIA) Impairement scale grade-A SCl. He had no motor or sensory function below T6 or in his sacral area. He had undergone operation within 6 hours after the injury and had a T5-7 total laminectomy and T3-11 posterolateral fusion (Figure 1). Postoperatively, his neurological status had not changed. One week after the operation, he reported a crude touch sensation between the T6 and T8 levels, but he was unable to discriminate the examining needle in his detailed neurological examination. No motor recovery or sacral sensory changes were noted. He had been admitted to physical therapy for 3 months, which increased the patient's level of participation in therapy without any improvement in the neurological function (Figure 2A, B; Table 1 and 2). At this stage, the patient was referred to our tertiary level hospital for the MSC trial.

\section{Enrollment Criteria}

The pilot study included the patient with $\mathrm{SCl}$, with contusions (preserved anatomical integrity of the spinal cord) confirmed by imaging studies [magnetic resonance imaging (MRI), etc.] and neurological examination and neurophysiological findings. Focal CNS lesions (e.g., neoplastic lesions) or chronic diseases (e.g., systemic diseases) that would require longterm pharmacotherapy would be exclusion criteria. Prior to the treatment, the patient was examined by the doctors in the neurosurgery and physical therapy and rehabilitation departments. The Wharton's jelly mesenchymal stem cells (WJ-MSC) implantation procedure was performed when the patient was stable, without contraindications for sedo-/general anesthesia from the viewpoint of internal medicine and without any serious infectious diseases, including sepsis, immediately prior to the procedure.

\section{PROCEDURE}

Umbilical cords were obtained from the Good Manufacturing Practice facility of LivMedCell (İstanbul, Turkey). All the umbilical cords were obtained from various donors after informed consent, as approved by an institutional regulatory board (LivMedCell). Postnatal umbilical cords were obtained from donors of full-term pregnancies. Recently, we represented the umbilical cord processing and quality control, characterization of WJ-MSCs by flow cytometry, cell differentiation and karyotyping, pre-transplantation process, and surgical procedure and WJ-MSC transplantation procedure in our previous publications (Table 3) (10,11). $^{(1)}$

\section{Clinical Evaluation and Statistical Analysis Pretreatment Neurological Examination}

The pretreatment assessment included extensive evaluation by a team of medical and rehabilitation experts (Suppl. Video 1). Detailed neurological and functional evaluation was documented in each step of the procedure (e.g.,ASIA). Spasticity

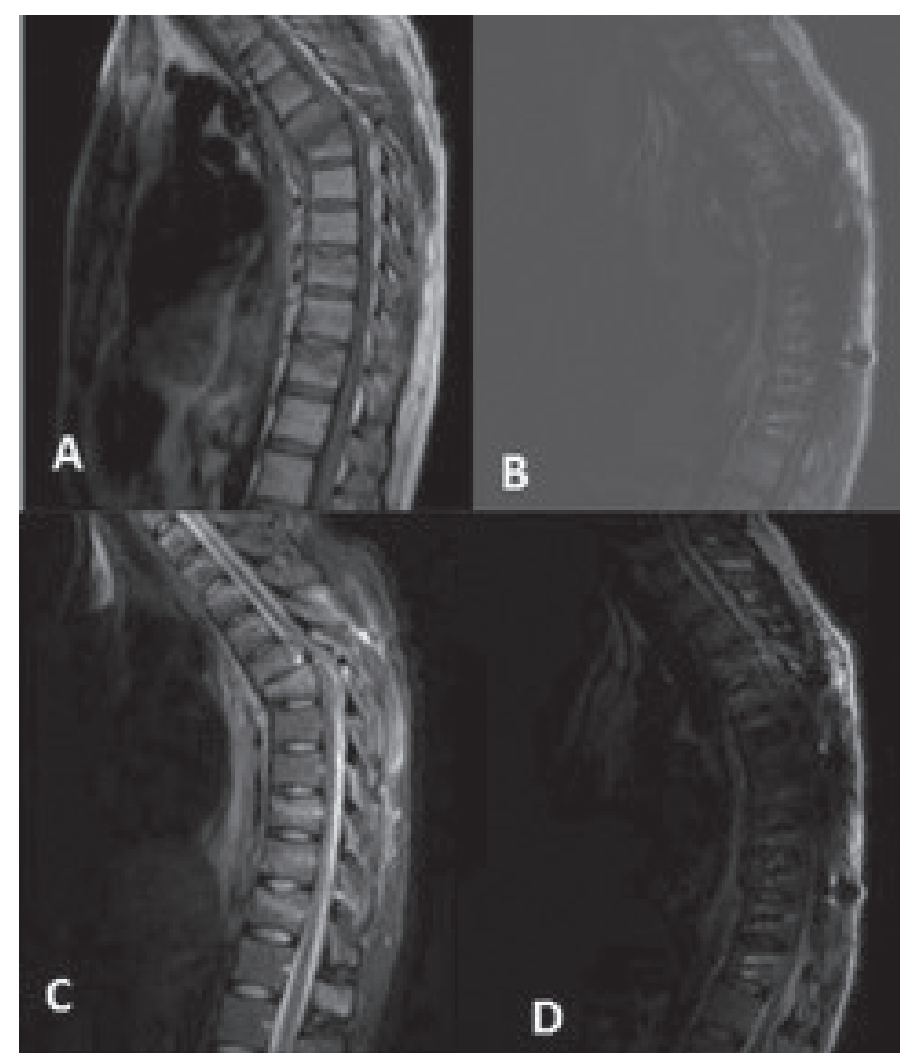

Figure 1. Spinal cord MRI including T1 sequences; (A) postop early, (B) 6 months a.f.i, spinal cord MRI including T2 sequences; (C) post-op early and (D) 6 months a.f.i. showed bilateral myelomalacia

MRI: Magnetic resonance imaging 
was assessed using the Modified Ashworth scale, and quality of life was assessed based on parental evaluation according to the Functional Independence Measure (FIM) scale $^{(12)}$.

\section{Safety Evaluation Criteria}

The safety criteria for the transplantation procedure included the appearance of infection, fever, headache, pain, an increased level of C-reactive protein, increased leukocytosis, allergic reaction/shock, and perioperative complications (anesthesia-and analgesiarelated complications, infections of the wound) for 7-14 days after the procedure. The safety criteria for using WJ-MSC included infection, neuropathic pain, cancer development, and deterioration of the neurological state, and they were assessed for a 1-year follow-up period.

Follow-up Assessment of Treatment Success

The follow-up evaluation consisted of a neurological examination evaluating motor function according to the Medical Research Council (MRC) Muscle Strength scale. The progression of the patient's sense was evaluated by detailed sensory examination. Clinical signs of efficacy were observed at 1 week, 1, 2, 3, and 9 months following the injection in both motor and sensory scores based on International Standards for Neurological Classification of Spinal Cord Injury (ISNCSCI) ${ }^{(13)}$. Spasticity was assessed using the Modified Ashworth scale, and quality of life was assessed based on the functional recovery estimated by the FIM scale ${ }^{(14)}$. In addition, an evaluation of the development of neuropathic pain, secondary infections, urinary tract infections, or pressure ulcers of the skin was performed.

\section{RESULTS}

\section{Safety and Adverse Events}

The patient tolerated the procedure well and did not experience any severe adverse events related to the injection. Our patient showed only early, transient complications, such as subfebrile fever, mild headache, and muscle pain due to intramuscular (i.m.) injection, which resolved in 24 hours (Table 4). Throughout the 1 year follow-up, no other safety issues or adverse events were reported.

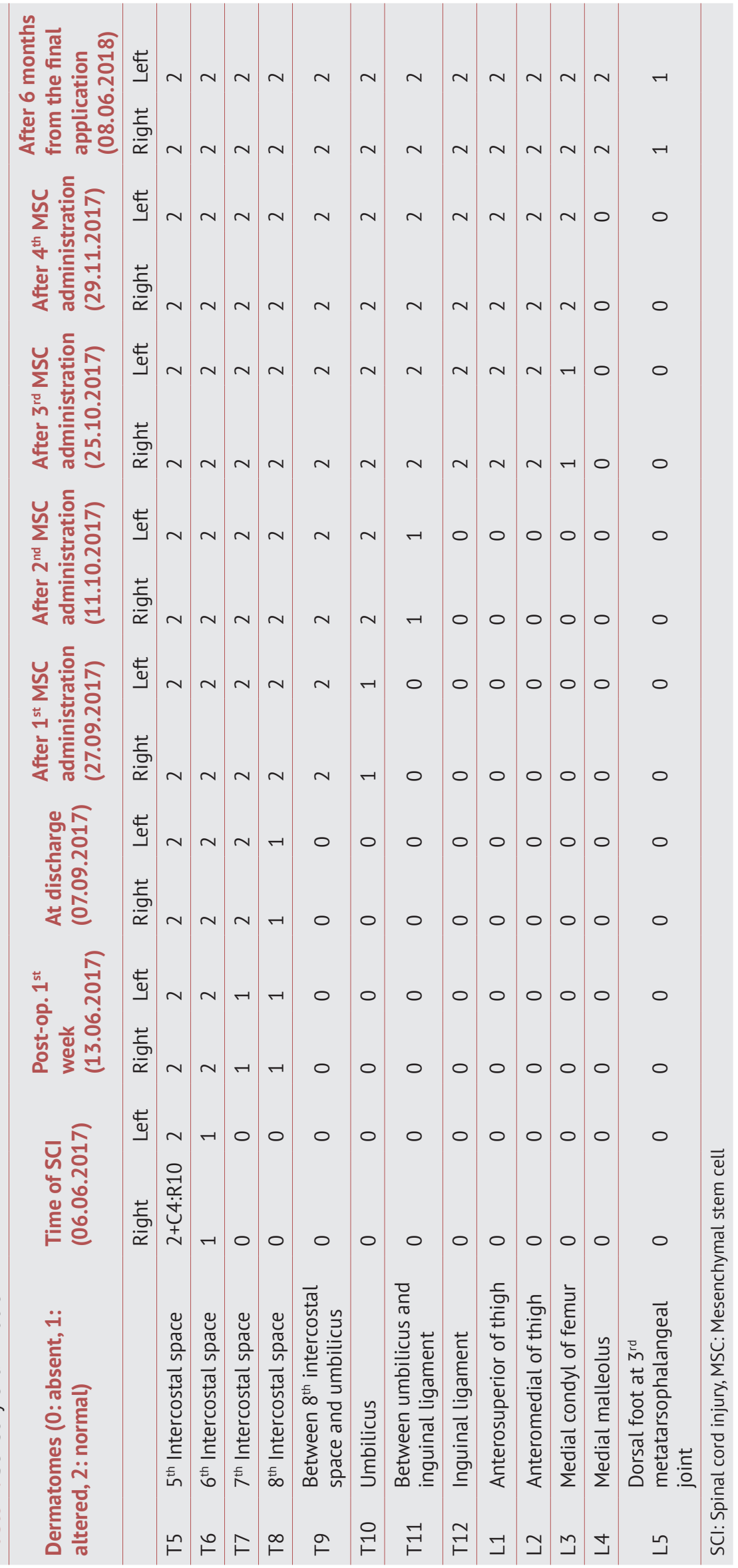




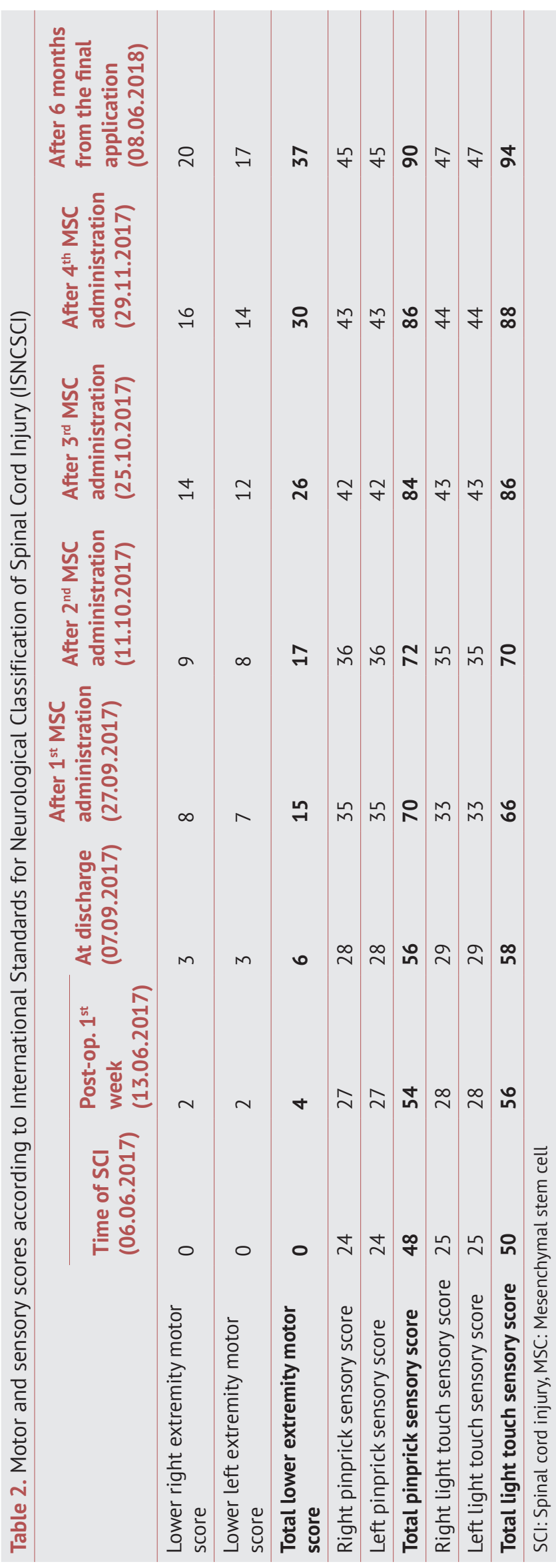

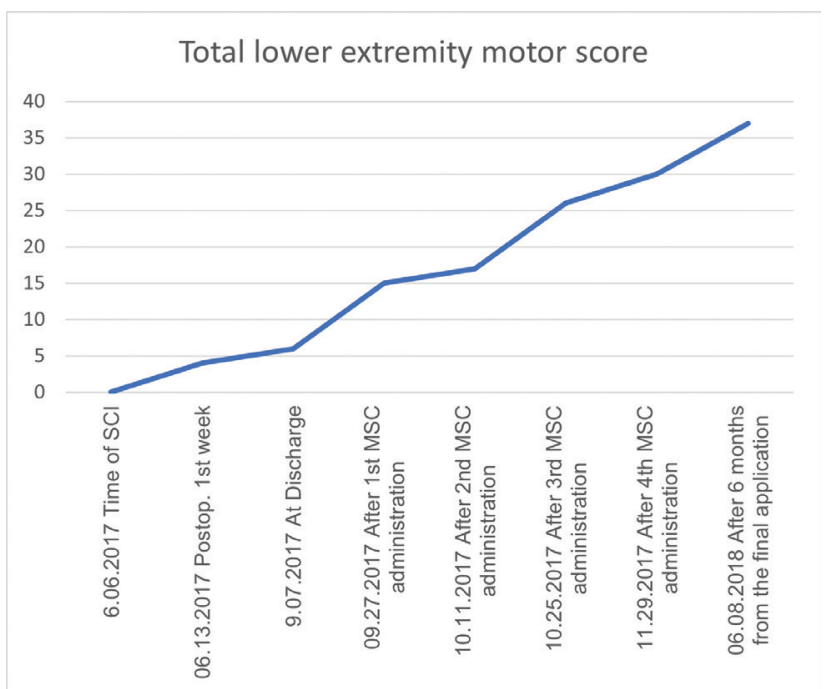
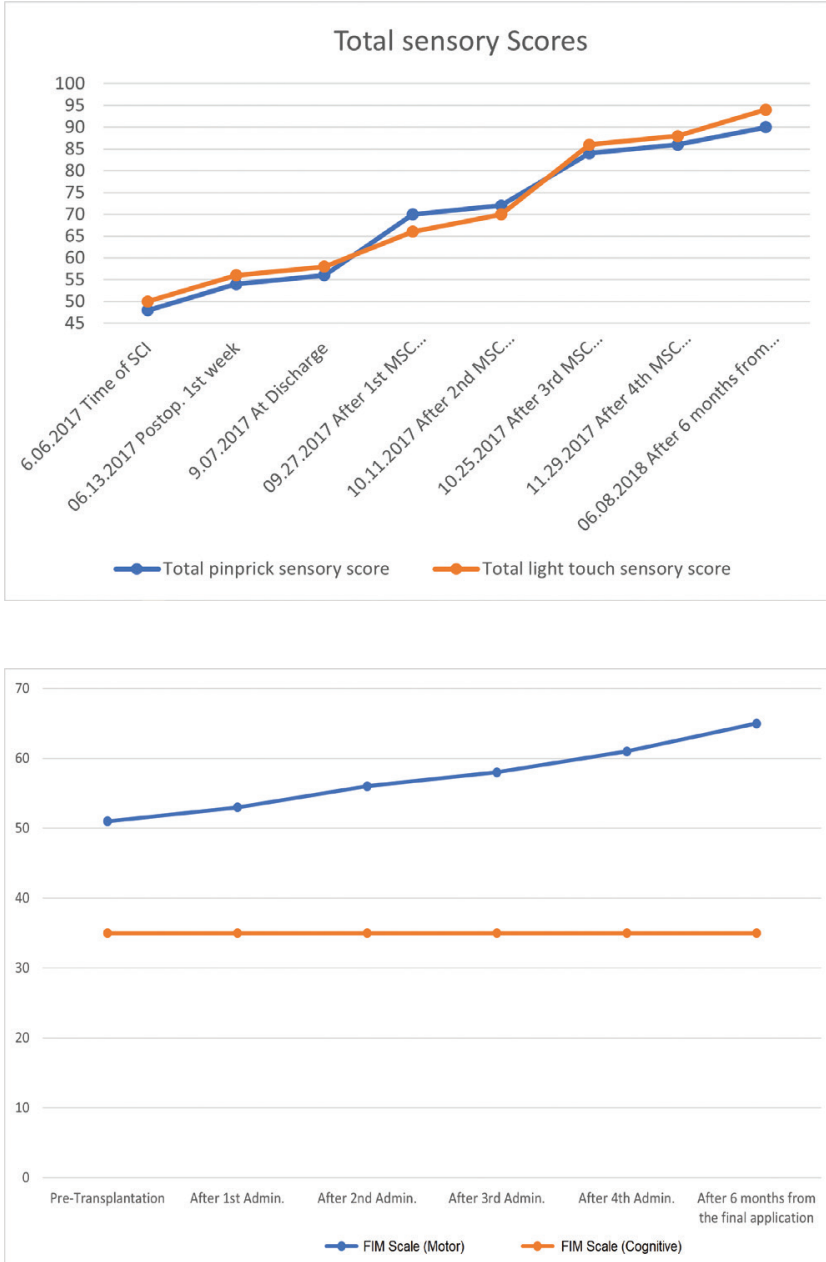

Figure 2. A, The total lower extremity motor score at all time points. B, Total pinprick and light touch sensory score at all time points. C, FIM scale scores at all time points.

FIM: Functional independence measurement, ISNCSCI: International Standards for Neurological Classification of Spinal Cord Injury 


\section{ASIA Motor Score}

The total lower extremity motor score progressively improved from 6 at baseline to 37 at 9 months, with more marked improvement on the right ( 3 at baseline to 20 at 9 months) with the left side (3 at baseline to 17 at 18 months) (Figure 2A; Table 2).

\section{ASIA Sensory Score}

The total pinprick score improved consistently at each time point from 56 at baseline to 90 at 9 months of follow-up. The improvement was similar on both sides, improving from 28 at to 45 at 9 months of follow-up. Similarly, total light touch score also improved on both sides 58 at baseline to 94 at 9 months of follow-up (Figure 2B; Table 2). We also examined the improvement in each dermatomal region. In the lower thoracic level, the improvement was substantially pronounced in the T10 region bilaterally after the first WJ-MSC application and so on. In the lower extremity, the patient experienced improvement in L4, L5 (Table 1).
Table 3. Administration schedule

\section{Date Route WJ-MSC}

\section{Round 1}

09.20 .2017 IT $1 \times 10 / \mathrm{kg}$ in $3 \mathrm{~mL}$ $09.20 .2017 \mathrm{IV} 1 \times 10 / \mathrm{kg}$ in $30 \mathrm{~mL}$ $09.20 .2017 \mathrm{IM} 1 \times 10_{6} / \mathrm{kg}$ in $20 \mathrm{~mL}$

\section{Round 2}

10.11.2017 IT $1 \times 10_{6} / \mathrm{kg}$ in $3 \mathrm{~mL}$ 10.11.2017 IV $1 \times 10_{6} / \mathrm{kg}$ in $30 \mathrm{~mL}$ 10.11.2017 IM $1 \times 10_{6} / \mathrm{kg}$ in $20 \mathrm{~mL}$

\section{Round 3}

10.18.2017 IT $1 \times 10_{6} / \mathrm{kg}$ in $3 \mathrm{~mL}$ 10.18.2017 IV $1 \times 10 / \mathrm{kg}$ in $30 \mathrm{~mL}$ 10.18.2017 IM $1 \times 10_{6} / \mathrm{kg}$ in $20 \mathrm{~mL}$

\section{Round 4}

11.22.2017 IT $1 \times 10 / \mathrm{kg}$ in $3 \mathrm{~mL}$ 11.22.2017 IV $1 \times 10 / \mathrm{kg}$ in $30 \mathrm{~mL}$ 11.22.2017 IM $1 \times 10_{6} / \mathrm{kg}$ in $20 \mathrm{~mL}$

IT: Intratekal, IV: Intravenous, IM: Intramuscular, WJ-MSC:Wharton's jellyderived mesenchymal stem cell

Table 4. Early and late complications of the proces

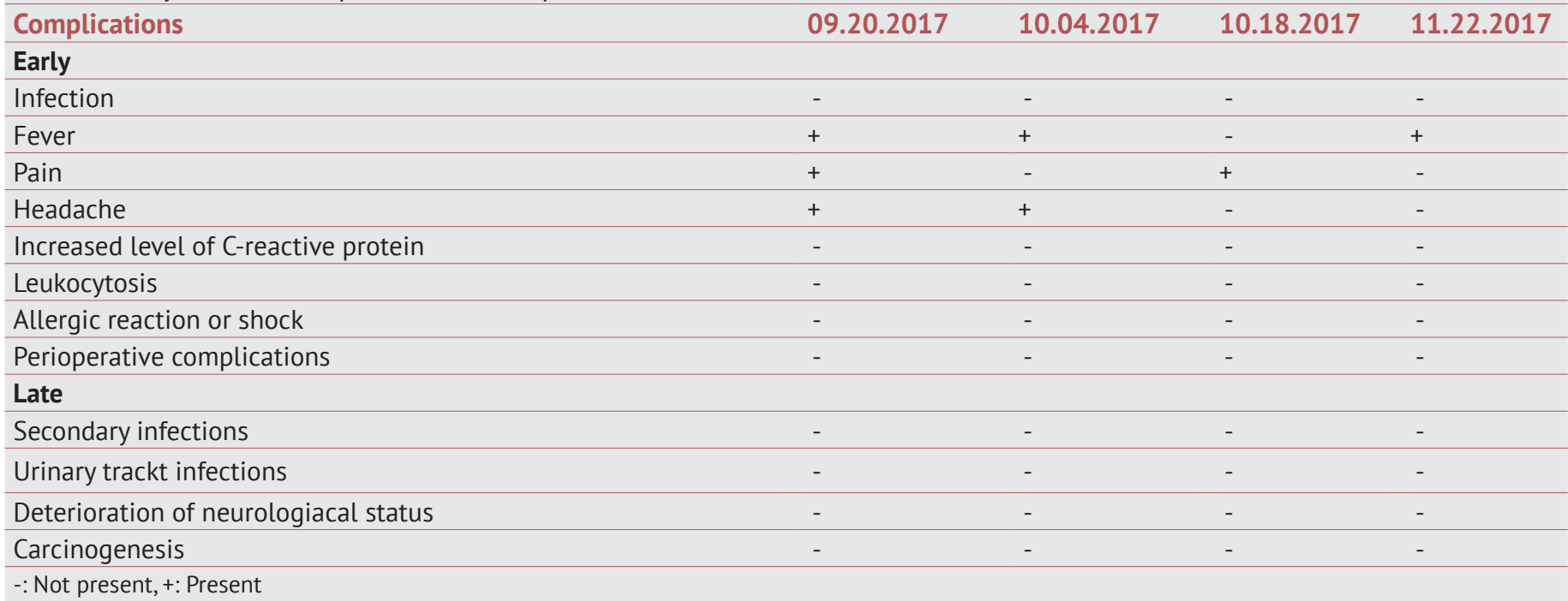

Table 5. Quailty-of-life improvement and spasticity evaluated with the use ot the FIM scale, modified ashworth grading and MRC muscle strength scale

\begin{tabular}{|c|c|c|c|c|c|c|c|c|c|c|c|c|c|c|}
\hline \multirow{3}{*}{$\begin{array}{l}\text { Evalualuation periods } \\
\text { (Pre and post- } \\
\text { transplantation) }\end{array}$} & \multicolumn{2}{|c|}{ FIM scale } & \multicolumn{6}{|c|}{ Modified ashworth scale } & \multicolumn{6}{|c|}{ MRC muscle strength scale } \\
\hline & \multicolumn{3}{|c|}{ Hips } & \multicolumn{2}{|c|}{ Knees } & \multicolumn{2}{|c|}{ Ankles } & \multicolumn{2}{|c|}{ Hips } & \multicolumn{2}{|c|}{ Knees } & \multicolumn{3}{|c|}{ Ankles } \\
\hline & Motor & Cognitive & Right & Left & Right & Left & Right & Left & Right & Left & Right & Left & Right & Left \\
\hline Pre-transplantation & 51 & 35 & 2 & 2 & 2 & 2 & 2 & 2 & 0 & 0 & 0 & 0 & 0 & 0 \\
\hline After $1^{\text {st }}$ admin. & 53 & 35 & 2 & 2 & 2 & 2 & 2 & 2 & 0 & 0 & 0 & 0 & 0 & 0 \\
\hline After $2^{\text {nd }}$ admin. & 56 & 35 & 2 & 2 & 2 & 2 & 2 & 2 & 1 & 1 & 0 & 0 & 0 & 0 \\
\hline After $3^{\text {rd }}$ admin. & 58 & 35 & $1+$ & $1+$ & $1+$ & $1+$ & $1+$ & $1+$ & 2 & 2 & 1 & 1 & 0 & 0 \\
\hline After $4^{\text {th }}$ admin. & 61 & 35 & $1+$ & $1+$ & $1+$ & $1+$ & $1+$ & $1+$ & 2 & 2 & 1 & 1 & 0 & 0 \\
\hline $\begin{array}{l}\text { After } 6 \text { months from the } \\
\text { final application }\end{array}$ & 65 & 35 & 1 & 1 & 1 & 1 & 1 & 1 & 2 & 2 & 2 & 2 & 1 & 1 \\
\hline
\end{tabular}

Admin: Administration, FIM: Functional independence measurement, MRC: Medical research council 
Table 6. Quality of life improvement evaluated with the use of the FIM scale

\begin{tabular}{|c|c|c|c|c|c|c|}
\hline Measurement & $\begin{array}{l}\text { Pre- } \\
\text { transplantation }\end{array}$ & $\begin{array}{l}\text { After } 1^{\text {st }} \\
\text { administration }\end{array}$ & $\begin{array}{l}\text { After } 2^{\text {nd }} \\
\text { administration }\end{array}$ & $\begin{array}{l}\text { After } 3^{\text {rd }} \\
\text { administration }\end{array}$ & $\begin{array}{l}\text { After } 4^{\text {th }} \\
\text { administration }\end{array}$ & $\begin{array}{l}\text { After } 6 \text { months } \\
\text { from the final } \\
\text { application }\end{array}$ \\
\hline \multicolumn{7}{|l|}{ Self care } \\
\hline Eating & 7 & 7 & 7 & 7 & 7 & 7 \\
\hline Grooming & 7 & 7 & 7 & 7 & 7 & 7 \\
\hline Bathing & 6 & 6 & 7 & 7 & 7 & 7 \\
\hline Dressing-upper body & 6 & 6 & 7 & 7 & 7 & 7 \\
\hline Dressing-lower body & 6 & 6 & 6 & 6 & 7 & 7 \\
\hline \multicolumn{7}{|l|}{ Toileting } \\
\hline \multicolumn{7}{|l|}{ Sphincter control } \\
\hline Bladder management & 1 & 1 & 1 & 1 & 1 & 1 \\
\hline Bowel management & 1 & 1 & 1 & 1 & 3 & 4 \\
\hline \multicolumn{7}{|l|}{ Transfer } \\
\hline Bed, chair, wheelchair & 5 & 5 & 5 & 5 & 5 & 7 \\
\hline Toilet & 5 & 5 & 6 & 6 & 6 & 7 \\
\hline Tub, shower & 5 & 5 & 5 & 6 & 6 & 6 \\
\hline \multicolumn{7}{|l|}{ Locomotion } \\
\hline Walk/wheelchair & 1 & 2 & 2 & 3 & 3 & 4 \\
\hline Starrs & 1 & 1 & 1 & 1 & 1 & 1 \\
\hline Motor subtotal score & 51 & 52 & 56 & 58 & 61 & 65 \\
\hline \multicolumn{7}{|l|}{ Communication } \\
\hline Comprehension & 7 & 7 & 7 & 7 & 7 & 7 \\
\hline Expressionr & 7 & 7 & 7 & 7 & 7 & 7 \\
\hline \multicolumn{7}{|l|}{ Social cognition } \\
\hline Social interaction & 7 & 7 & 7 & 7 & 7 & 7 \\
\hline Problem solving & 7 & 7 & 7 & 7 & 7 & 7 \\
\hline Memory & 7 & 7 & 7 & 7 & 7 & 7 \\
\hline Cognitive subtotal score & 35 & 35 & 35 & 35 & 35 & 35 \\
\hline Total FIM score & 86 & 88 & 91 & 93 & 96 & 100 \\
\hline
\end{tabular}

FIM: Functional independence measurement, FIM scale in detail; 7 Points: Complete independence, 6 Points: Modified independence, 5 Points:

Supervision, 4 points: Minimal assistance, 3 Points: Moderate assistance, 2 Points: Maximal assistance and 1 Point: Total Assistance or not testable. Total motor score: 91 points, total cognitive score: 35, and total FIM score is 126

\section{FIM Scale Score}

Substantial improvement in quality of life was observed, as assessed using the FIM scale 6 main questionnaire including motor and cognitive scores. The total FIM Scale score improved from $86 / 126$ at baseline to $100 / 126$ at 9 months. The total motor score improved consistently at each time point from 51 at baseline to 65 at 9 months of follow-up. The total cognitive score was 35 and remained stable at 9 months of follow-up (Figure 2C; Table 5,6).

\section{Modified Ashworth and MRC Muscle Strength Scale}

The Modified Ashworth Scale score was similar on both sides, improving from 2 at baseline to 1 at 9 months of follow-up. Similarly, MRC Muscle Strength scale score also improved on both sides from 0 at baseline to 2 in his knees and hips at 9
Table 7. Summary of the neuroradiological and neurophysilogical findings using MRI and EMG before and after treatment

\begin{tabular}{lll}
\multirow{2}{*}{ MRI } & Date & MRI appearance of cord \\
\cline { 2 - 3 } & Pre-t.p. & Ischemia (T2 hyperintensity) \\
\cline { 2 - 3 } & Post-t.p. & Bilateral myelomalacia \\
\hline \multirow{2}{*}{ EMG } & Date & EMG findings \\
\cline { 2 - 3 } & Pre-t.p. & Upper motor neuron involvement \\
\cline { 2 - 3 } & Post-t.p. & Not present \\
\end{tabular}

MRI: Magnetic resonance imaging, EMG: Electomyography, t.p.: transplantation 
months of follow-up. On the other hand, MRC Muscle Strength scale score improved on both sides from 0 at baseline to 1 in his ankles at 9 months of follow-up (Table 5).

\section{Neuroradiological and Neurophysilogical Findings}

In the early postoperative spinal cord MRI, there was ischemia (T2 hyperintensity) in the injured thoracic spinal cord (T6). On repeating spinal cord MRI at 3 months after the first interventation (a.f.i.), there was bilateral myelomalacia in the injured thoracic spinal cord (T6). In the electromyographic (EMG) a.i.f readings showed normal motor and sensory transmission without firing of motor unit potentials, revealing an upper motor neuron lesion in accordance with the original spinal cord lesion at T6. Post-transplantation EMG wasn't presented due to clinical improvement of the patient (Data not shown) (Figure 1; Table 7).

\section{Physical Therapy}

We also observed considerable improvement in physical therapy at follow-up. Starting from the first transplantation, the patient underwent intensive neurorehabilitation that included physiotherapy as a part of the treatment program. The patient was placed on a personalized exercise program that emphasized techniques for facilitating mobility and the multiplication of the injected stem cells, thereby giving enhanced results. The personalized program comprised one session (50 min.) per day, 5 times a week, including posture, balance, range of motion and strength and stretch exercises. On the stem cell application days, the exercise program was interrupted. After 1 week following the initial administration of MSCs, the patient mentioned that he had gained some sensation back in previously numb areas (T6-10 dermatomes). Two weeks later, a $2^{\text {nd }}$ administration of MSC resulted in improved sensation between the T6 and T11 dermatomes, just below the umbilicus. A $3^{\text {rd }}$ MSC administration resulted in sensory extension down to the L2-3 dermatomes (Table 1; Suppl. Video 2). After the $4^{\text {th }}$ MSC administration, the patient began to show marked improvements. His trunk balance and control improved; the patient could walk with bilateral push knee splints and elbow crutches (Suppl. Video 3). The patient has been followed up every 6 months thereafter to further assess his progress. He was walking with a walker and his motor functions improved in this time frame. According to the ASIA scale assessment, he had changed from ASIA A to ASIA C during a 1 year period (Suppl. Video 4).

\section{DISCUSSION}

$\mathrm{SCl}$ is a severe, debilitating injury, not just because of the loss of neurological function but also the psychological and social burdens the patients, families, and society as a whole have to face. Previously, it was thought that the CNS was unable to regenerate; however, several studies have suggested that alterations to the local environment of the injury site may aid the regeneration of nerve cells ${ }^{(15)}$. These alterations include transplantation of fetal spinal cord tissue, peripheral nerves, Schwann cells, and fibroblasts, as well as removal of nerve growth inhibitory factors ${ }^{(16-18)}$.

Aras et al. ${ }^{(19)}$ suggested that the transplantation of MSCs derived from different tissues improved the locomotor recovery following $\mathrm{SCl}$, and the capacity of rat adipose tissue-derived (rAT)-MSCs to differentiate into the oligodendrocyte lineage improved the functional recovery. An important point of this study was the determination of the ideal transplantation time: The results revealed that the local conditions at the time of the transplantation were important for the cell behavior ${ }^{(19)}$. Moreover, Kabatas et al. ${ }^{(20)}$ suggested that the MSCs can be isolated from the dental pulp and cultured and passaged in vitro. After transplantation of the passaged MSCs into rats with $\mathrm{SCl}$, the isolated $\mathrm{MSC}$ can survive in rat bodies without any immune rejection. The implanted MSCs can differentiate into nerve cells, and they are involved in the recovery of the damaged spinal cord. This improves the scores of motion behavior and promotes the recovery of motor function after $\mathrm{SCI}^{(20)}$. All these results provide a theoretical and experimental basis for MSC transplantation applied in the treatment of SCI. Previously, we reported on the safety and feasibility of both the triple route and multiple WJ-MSC implantations, using this treatment strategy in a patient with hypoxicischemic encephalopathy ${ }^{(10)}$. As the studies have been further improved and deepened, it is now possible to apply WJ-MSC transplantation to the clinical treatment of $\mathrm{SCl}$. In this article, we present a patient with a blunt, traumatic $\mathrm{SCl}$ who was treated with WJ-MSC therapy. MSCs, also known as mesenchymal progenitor cells, are selfrenewing, multipotent progenitor cells that can differentiate into different mesodermal tissues ranging from bone and cartilage to cardiac muscle ${ }^{(21)}$. They have been advocated as a promising novel treatment strategy for patients with $\mathrm{SCl}^{(22)}$. Previously, bone marrow (BM) was considered a good candidate as a source of MSCs. However, since BM aspiration is an invasive procedure and the proliferation and differentiation capacity of cells decreases with donor age, alternative sources of stem cells were pursued. Fetal-derived MSCs, which are more primitive and have less immune reactivity, have recently been suggested as better alternatives for BM-MSCs.

The primitive connective tissue of the umbilical cord between the umbilical vessels and amniotic membrane is known as "Wharton's jelly," and it protects fetal umbilical vessels from compression and torsion. During embryogenesis, hematopoietic and mesenchymal cells migrate through the WJ, and some of them become trapped, making this tissue a good source of MSCs ${ }^{(23-25)}$. Stem cell therapy $(\mathrm{SCT})$ for $\mathrm{SCl}$ involves acquiring endogenous stem cells in vivo, harvesting or altering them ex vivo and transplanting them into the injured site, thereby promoting neuronal regeneration and the secretion of neurotrophic molecules ${ }^{(26)}$. Harvesting protocols and isolation methods may vary among different institutes. Animal studies using transplanted human umbilical MSC-derived neurospheres 
on transected $\mathrm{SCl}$ rat models have shown recovery of hindlimb motor function at 5 weeks compared with control groups without MSC therapy ${ }^{(27)}$.

Various studies have demonstrated that MSCs display their therapeutic benefits via paracrine regulation with growth factors and cytokines ${ }^{(28)}$. In a previous study, we suggested that, after performing $\mathrm{SCl}$, the injection of rPI-SCs is likely to prevent immune cell activation, and especially, to reduce the secretion of proinflammatory cytokines (e.g., interleukin-6) as possible direct markers of spinal cord inflammation. Inhibition of these inflammation factors positively affects the $\mathrm{SCl}$ healing process $^{(9)}$. In addition, Németh et al. ${ }^{(29)}$ demonstrated that anti-inflammatory mediators (e.g., IL-1ra) increased after MSC treatment. We also demonstrated that rPI-SC administration was found to be effective for increasing the intensity of IL-1ra in the injured area of the spinal cord, suggesting an anti-inflammatory role for these cells ${ }^{(9,29)}$. Our patient had four cycles of intrathecal (i.t.), intravenous (i.v.) and i.m. MSC injections at 2 week intervals starting 3 and a half months after $\mathrm{SCl}$ from a fall. With SCT and intensive neurorehabilitation, he showed moderate improvements in bowel control. His physical examination revealed gradual improvement in sensation down to 11 levels (9 levels a.f.i) below the level of his lesion, and his motor function improved in stages. On the other hand, treatment involving SCT combined with physiotherapy (as a supportive therapy) offers a tremendous opportunity for patients with neurological disorders, e.g., after $\mathrm{SCl}$. The rehabilitation itself could prevent the process of muscle atrophy and joint stifness, but it cannot repair the damaged nerve function ${ }^{(30)}$. This improvement is thought to be related to the migration of MSCs to the injury site and promotion of neuroregenerative mechanisms there. On the other hand, it is important in such cases to distinguish gains attributable to therapy from spontaneous recovery following the injury ${ }^{(31)}$. In the current report, we have presented both subjective (physical therapy reports) and objective (ISNCSCI, FIM, Modified Ashworth and MRC Muscle Strength Scales' scores) measures to demonstrate that the patient, after reaching a plateau of spontaneous improvement at 3 and a half months postinjury, experienced improvement in neurological and functional status.

\section{CONCLUSION}

Therapeutic administration of stem cells has a theoretical role in the treatment of $\mathrm{SCl}$, and this is supported by many preliminary clinical studies in the literature; no serious adverse effects of this therapy have been documented to date. Although promising results from many publications have been reported, there is still no consensus on which cellular therapy should be administered to which patient at what time after $\mathrm{SCl}$. There seems to be a need for a tremendous amount of work to elucidate the underlying mechanisms of how MSCs interact with damaged host tissues and how this interaction results in a cascade of events that lead to some functional neuronal recovery. These findings suggest that quality of the cells, optimization of the cell dose, standardization of the cell processing, the timing, route of administration and patient selection as well as the role of clinical experience of the physcisian are critical to the success of $\mathrm{SCT}$ in $\mathrm{SCl}$ patients.

\section{Ethics}

Ethics Committee Approval: Ethical approval to report this case was obtained from the IRB of Turkish Ministry of Health, Department of Organ, Tissue Transplant and Dialysis Services' Scientific Committee (protocol number: 56733164-203-E.2569), Ankara, Turkey.

Informed Consent: The patient was informed of the procedure, and a written informed consent form was obtained per the Helsinki Declaration.

Peer-review: Internally peer-reviewed.

\section{Authorship Contributions}

Concept: S.K., E.K., Design: S.K., E.K., Data Collection or Processing: S.K., E.C., E.C.S., N.K., E.Ç., F.D., O.B., G.G., Analysis or Interpretation: S.K., E.C., E.C.S., N.K., E.Ç., F.D., O.B., G.G., Literature Search: S.K., E.C., E.K., Writing: S.K., E.C., E.C.S., N.K.

Conflict of Interest: The authors declare that they have no conflict of interest.

Financial Disclosure: The authors received no financial support for the research, authorship, and/or publication of this article.

\section{REFERENCES}

1. Devivo MJ. Epidemiology of traumatic spinal cord injury: trends and future implications. Spinal Cord. 2012;50:365-72.

2. Kim YH, Ha KY, Kim SI. Spinal cord injury and related clinical trials. Clin Orthop Surg. 2017;9:1-9.

3. Sekhon LH, Fehlings MG. Epidemiology, demographics, and pathophysiology of acute spinal cord injury. Spine (Phila Pa 1976). 2001;26(24 Suppl):2-12.

4. Bramlett HM, Dietrich WD. Progressive damage after brain and spinal cord injury: pathomechanisms and treatment strategies. Prog Brain Res. 2007;161:125-41.

5. Park E, Velumian AA, Fehlings MG. The role of excitotoxicity in secondary mechanisms of spinal cord injury: a review with an emphasis on the implications for White matter degeneration. J Neurotrauma. 2004;21:754-74.

6. Gholaminejhad M, Arabzadeh S, Akbari M, Mohamadi Y, Hassanzadeh G. Anti-oxidative and neuroprotective effects of flaxseed on experimental unilateral spinal cord injury in rat. J Contemp Med Sci. 2017;3:213-7.

7. ljaz S, Mohammed I, Gholaminejhad M, Mokhtari T, Akbari M, Hassanzadeh G. Modulating pro-inflammatory cytokines, tissue damage magnitude, and motor deficit in spinal cord injury with subventricular zone-derived extracellular vesicles. J Mol Neurosci. 2020;70:458-66.

8. Bracken MB. Steroids for acute spinal cord injury. Cochrane Database Syst Rev. 2012;1:CD001046.

9. Karaoz E, Tepekoy F, Yilmaz I, Subasi C, Kabatas S. Reduction of Inflammation and enhancement of motility after pancreatic islet derived stem cell transplantation following spinal cord ınjury. J Korean Neurosurg Soc. 2019;62:153-65.

10. Kabataş S, Civelek E, İnci Ç, Yalçınkaya EY, Günel G, Kır G, et al. Wharton's jelly-derived mesenchymal stem cell transplantation in a 
turkishspine

patient with hypoxic-ischemic encephalopathy: a pilot study. Cell Transplant. 2018;27:1425-33.

11. Okur SÇ, Erdoğan S, Demir CS, Günel G, Karaöz E. The effect of umbilical cord-derived mesenchymal stem cell transplantation in a patient with cerebral palsy: a case report. Int J Stem Cells. 2018;11:141-7.

12. Huang H, Young W, Chen L, Feng S, Zoubi ZMA, Sharma HS, et al. Clinical cell therapy guidelines for neurorestoration (IANR/CANR 2017). Cell Transplant. 2018;27:310-24.

13. Osunronbi T, Sharma H. International standards for neurological classification of spinal cord injury: factors influencing the frequency, completion and accuracy of documentation of neurology for patients with traumatic spinal cord injuries. Eur J Orthop Surg Traumatol. 2019;29:1639-48.

14. Thorpe ER, Garrett KB, Smith AM, Reneker JC, Phillips RS. Outcome measure scores predict discharge destination in patients with acute and subacute stroke: a systematic review and series of meta-analyses. J Neurol Phys Ther. 2018;42:2-11.

15. Blesch A, Lu P, Tuszynski MH. Neurotrophic factors, gene therapy, and neural stem cells for spinal cord repair. Brain Res Bull. 2002;57:833-8.

16. Girard C, Bemelmans AP, Dufour N, Mallet J, Bachelin C, NaitOumesmar B, et al. Grafts of brain-derived neurotrophic factor and neurotrophin 3-transduced primate schwann cells lead to functional recovery of the demyelinated mouse spinal cord. J Neurosci. 2005;25:7924-33.

17. Kuh SU, Cho YE, Yoon DH, Kim KN, Ha Y. Functional recovery after human umbilical cord blood cells transplantation with brain-derived neutrophic factor into the spinal cord injured rat. Acta Neurochir (Wien). 2005;147:985-92.

18. Zhao ZM, Li HJ, Liu HY, Lu SH, Yang RC, Zhang QJ, et al. Intraspinal transplantation of CD34+ human umbilical cord blood cells after spinal cord hemisection injury improves functional recovery in adult rats. Cell Transplant 2004;13:113-22.

19. Aras Y, Sabanci PA, Kabatas S, Duruksu G, Subasi C, Erguven M, et al. The effects of adipose tissue-derived mesenchymal stem cell transplantation during the acute and subacute phases following spinal cord injury. Turk Neurosurg. 2016;26:127-39.

20. Kabatas S, Demir CS, Civelek E, Yilmaz I, Kircelli A, Yilmaz C, et al. Neuronal regeneration in injured rat spinal cord after human dental pulp derived neural crest stem cell transplantation. Bratisl Lek Listy. 2018;119:143-51.

21. Malgieri A, Kantzari E, Patrizi MP, Gambardella S. Bone marrow and umbilical cord blood human mesenchymal stem cells: state of the art. Int J Clin Exp Med. 2010;3:248-69.

22. Li J, Lepski G. Cell transplantation for spinal cord injury: a systematic review. Biomed Res Int. 2013;2013:786475

23. Witkowska-Zimny M, Wrobel E. Perinatal sources of mesenchymal stem cells:Wharton's jelly, amnion and chorion. Cell Mol Biol Lett. 2011;16:493-514.

24. In 't Anker PS, Scherjon SA, Kleijburg-van der Keur C, de GrootSwings GM, Claas FH, Fibbe WE, et al. Isolation of mesenchymal stem cells of fetal or maternal origin from human placenta. Stem Cells. 2004;22:1338-45.

25. Wang XY, Lan Y, He WY, Zhang L, Yao HY, Hou CM, et al. Identification of mesenchymal stem cells in aorta-gonad-mesonephrosand yolk sac of human embryos. Blood. 2008;111:2436-43.

26. Pearse DD, Bunge M. Designing cell-and gene-based regeneration strategies to repairthe injured spinal cord. J Neurotrauma. 2006;233:437-52.

27. Zhang L, Zhang HT, Hong SQ, Ma X, Jiang XD, Xu RX. Cografted Wharton'sjelly cells-derived neurospheres and BDNF promote functional recovery after rat spinal cordtransection. Neurochem Res. 2009;34:2030-9.

28. Aggarwal S, Pittenger MF. Human mesenchymal stem cells modulate allogeneic immune cell responses. Blood. 2005;105:1815-22.

29. Németh K, Leelahavanichkul A, Yuen PS, Mayer B, Parmelee A, Doi $\mathrm{K}$, et al. Bone marrow stromal cells attenuate sepsis via prostaglandin $\mathrm{E}(2)$-dependent reprogramming of host macrophages to increase theirinterleukin-10 production. Nat Med. 2009;15:42-9.

30. Kamelska-Sadowska AM, Wojtkiewicz J, Kowalski IM. Review of the current knowledge on the role of stem cell transplantation in neurorehabilitation. Biomed Res Int. 2019;25;3290894.

31. Bydon M, Dietz AB, Goncalves S, Moinuddin FM, Alvi MA, Goyal $A$, et al. CELLTOP clinical trial: first report from a phase 1 trial of autologous adipose tissue-derived mesenchymal stem cells in the treatment of paralysis due to traumatic spinal cord injury. Mayo Clin Proc. 2020;95:406-14.

Video 1.

https://www.doi.org/10.4274/jtss.galenos.2021.363.video1

Video 2.

https://www.doi.org/10.4274/jtss.galenos.2021.363.video2

Video 3.

https://www.doi.org/10.4274/jtss.galenos.2021.363.video3

Video 4.

https://www.doi.org/10.4274/jtss.galenos.2021.363.video4 